\title{
1
}

\section{Introduction: Why Entrepreneurship?}

In 2005, Harvard professor Benjamin Friedman published the book The Moral Consequences of Economic Growth. His message was depressing in its simplicity: economic stagnation is a threat to liberal democracy, as it ushers in xenophobia and political populism of all colors. Today, amid sluggish growth and rising inequality, populism is on the rise. The liberal political and economic order of the EU, which Fukuyama (1989) suggested was a more likely candidate than the communist utopia for "the end of history," faces what may be its most formidable challenge since the rise of communism.

This book is written to help address this challenge. In line with the view expressed by Karl Popper in his book The Open Society and Its Enemies (1945), we believe that a healthy society is a contestable society. Contestability ensures opportunity, freedom, and progress. From that perspective, growth and innovation are as much a manifestation of freedom as they are a precondition for a sustainable liberal democratic order. Europe needs an optimistic and compelling new perspective if it is to regain its legitimacy among large parts of its population. In a stagnant economy, people no longer see the opportunities for improvement and turn to strong leaders who blame outsiders and promise to make things right. In a truly entrepreneurial Europe in which all are empowered to participate, their simplistic recipes will lose much of their appeal. Reforms enabling smart, inclusive, and sustainable growth across the entire EU could, therefore, offer a way out of the present, perilous situation. The academic consensus on the importance of an economy that innovates in a 
sustainable direction and offers opportunities to all lends urgency to our agenda. ${ }^{1}$

Economic stagnation in Europe arguably relates to a lack of innovation, which the EU itself acknowledges: when the European Commission launched the "Innovation Union," a flagship initiative of the EU's 2020 strategy, it simultaneously stressed that the EU was "facing a situation of "innovation emergency" (European Commission 2015b). ${ }^{2}$ This stark conclusion followed the observation that European member states were gradually slipping out of the top positions in global rankings on innovation. In Table 1.1, we present recent rankings of the top 20 countries according to the most commonly used measures for innovativeness. As can be seen, the USA consistently ranks higher than European countries, as do the Asian Tigers Singapore and Hong Kong. Nonetheless, half of the top 20 countries in all rankings are European; in particular, Nordic and Western European countries continue to do well. By contrast, southern and eastern EU member states are virtually absent in the rankings, hinting at Europe's well-known core-periphery pattern.

In view of this evidence, it is troubling that a key term is missing from the Commission's statement warning of the Union's innovation emergency. Despite acknowledging that " $[\mathrm{w}] \mathrm{e}$ need to do much better at turning our research into new and better services and products if we are to remain competitive in the global marketplace and improve the quality of life in Europe," the authors do not mention the word "entrepreneurship" once. One is reminded of economist William Baumol's (1968) lament 50 years ago that economics without the entrepreneur is like Hamlet without the Prince of Denmark. Since this statement was made, the economics profession has come to acknowledge the importance of the entrepreneur; the same does not seem to be the case for the EU's top policymakers.

Our starting point when tackling Europe's innovation emergency is that entrepreneurship — broadly defined as the act of challenging the status quo by introducing novelty into the economic realm-must be a central theme of such a strategy. While entrepreneurship is a multifaceted concept, we are convinced that particular emphasis must be placed on what has come to be called Schumpeterian entrepreneurship: the kind of entrepreneurship that intro-

\footnotetext{
${ }^{1}$ As the reasoning suggests, macroeconomics is not a part of this book. Instead, we believe that issues related to fiscal and monetary stimulus and the survival of the EU serve to distract from the structural transformation the EU must undertake in order to achieve sustainable growth. Åslund and Djankov (2017, pp. 5-7) develop this argument in more detail.

${ }^{2}$ See http://ec.europa.eu/research/innovation-union/index_en.cfm?pg=why.
} 
Table 1.1 Country ranking according to the five most commonly used measures of national innovativeness, top 20 countries for the last available year

\begin{tabular}{|c|c|c|c|c|c|}
\hline Rank & $\begin{array}{l}\text { IMD world } \\
\text { competitiveness } \\
\text { ranking } 2018\end{array}$ & $\begin{array}{l}\text { WEF global } \\
\text { competitiveness } \\
\text { index } 2018\end{array}$ & $\begin{array}{l}\text { Global } \\
\text { innovation } \\
\text { index } 2018 \\
\text { (INSEAD, } \\
\text { Cornell, } \\
\text { WIPO) }\end{array}$ & $\begin{array}{l}\text { No. of triadic } \\
\text { patents per } \\
\text { capita } 2013^{a}\end{array}$ & $\begin{array}{l}\text { R\&D } \\
\text { spending as a } \\
\text { share of GDP } \\
2016\end{array}$ \\
\hline 1 & USA & USA & Switzerland & Switzerland & Israel \\
\hline 2 & Hong Kong & Singapore & Netherlands & Japan & South Korea \\
\hline 3 & Singapore & Germany & Sweden & Germany & Sweden \\
\hline 4 & Netherlands & Switzerland & UK & Sweden & Japan \\
\hline 5 & Switzerland & Japan & Singapore & Denmark & Austria \\
\hline 6 & Denmark & Netherlands & USA & South Korea & Germany \\
\hline 7 & UAE & Hong Kong & Finland & Austria & Denmark \\
\hline 8 & Norway & UK & Denmark & Netherlands & Finland \\
\hline 9 & Sweden & Sweden & Germany & Israel & USA \\
\hline 10 & Canada & Denmark & Ireland & USA & Belgium \\
\hline 11 & Luxembourg & Finland & Israel & Finland & France \\
\hline 12 & Ireland & Canada & South Korea & Belgium & China \\
\hline 13 & China & Taiwan & Japan & France & Iceland \\
\hline 14 & Qatar & Australia & Hong Kong & Luxembourg & Netherlands \\
\hline 15 & Germany & South Korea & Luxembourg & UK & Norway \\
\hline 16 & Finland & Norway & France & Norway & Slovenia \\
\hline 17 & Taiwan & France & China & Ireland & UK \\
\hline 18 & Austria & New Zealand & Canada & Canada & Czech Rep. \\
\hline 19 & Australia & Luxembourg & Norway & Australia & Canada \\
\hline 20 & UK & Israel & Australia & Italy & Italy \\
\hline
\end{tabular}

Sources: IMD World Competitiveness Yearbook 2018; World Economic Forum, Global Competitiveness Report 2018; The Global Innovation Index 2018-Energizing the World with Innovation (INSEAD, Cornell University and WIPO); OECD Factbook 20152016: Economic, Environmental and Social Statistics; OECD Statistics

${ }^{a}$ Triadic patent families are a set of patents filed at three of the major patent offices: the European Patent Office (EPO), the Japan Patent Office (JPO), and the United States Patent and Trademark Office (USPTO). Patents included in the triadic family are typically of higher economic value

duces new products and technologies and serves as a conduit of knowledge to generate innovation and growth (Schumpeter 1934 [1911]). ${ }^{3}$

The evidence is clear that innovation promotes the further diffusion and creation of knowledge and ultimately drives economic progress (Romer 1986, 1990; Aghion and Howitt 1992; Grossman and Helpman 1991; Jones 1995,

\footnotetext{
${ }^{3}$ In Schumpeterian terms, innovation is the creation of new combinations, generally of (old and new) knowledge, resulting in a new product, a new method of production, the opening of a new market, the conquest of a new source of supply, or the carrying out of a new organization of industry (Schumpeter 1934, p. 66; OECD 2010).
} 
2005). Crucially, Schumpeter saw the entrepreneur, the agent responsible for introducing such innovation into the market, as the primus motor of economic growth. However, finding suitable empirical proxies for such entrepreneurship has proven difficult. ${ }^{4}$ To this day, a fierce debate in the literature continues to confuse Schumpeter's clearly defined theoretical concept and the inherently imprecise proxies for entrepreneurship provided by empirical data. In our view, the empirical definition of entrepreneurship is less relevant. What matters for our purposes are the qualitative aspects of entrepreneurship; empirical evidence taking these aspects into account suggests that an economy that fosters high-growth firms and high-impact entrepreneurial firms grows faster than an economy with high numbers of small- and medium-sized enterprises (SMEs) or a high self-employment rate (Shane 2008; Henrekson and Sanandaji 2014, 2019). But for this growth to be inclusive as well as innovative, others have emphasized the importance of a broad base of active "everyday entrepreneurs" (Welter et al. 2017).

Table 1.2 presents four measures of Schumpeterian entrepreneurship together with the self-employment rate for Western Europe, Eastern Europe, the USA, China, and East Asia. While the self-employment rate is considerably lower in the USA than in Western Europe and East Asia, the number of US billionaire entrepreneurs per capita-a measure indicative of successful Schumpeterian entrepreneurship-is three times greater. The other approximations of Schumpeterian entrepreneurship reveal a similar picture: total venture capital (VC) investment as a share of GDP is five times greater in the USA than in Western Europe. ${ }^{5}$ Furthermore, the number of large firms founded by entrepreneurs since 1990 is more than three times greater in the USA despite Western Europe's much larger population, and the number of unicorns (privately held start-up companies valued at over USD 1 billion as determined by private or public investment) per capita is almost seven times greater.

Western Europe trumps East Asia only in terms of the number of unicorns and is on a par in terms of VC investment as a share of GDP; it scores clearly below East Asia based on the number of billionaire entrepreneurs per capita and the number of large firms founded by entrepreneurs since 1990. Eastern Europe, meanwhile, scores below both East Asia and China on all four measures and has the highest rate of self-employment (partly reflecting its sizable

\footnotetext{
${ }^{4}$ As Acs et al. (2014, p. 476) state: "In spite of years of research, entrepreneurship is a fiendishly difficult concept to pin down". Anderson and Starnawska also (2008, p. 224) note: "more than two decades of concentrated endeavor have failed to produce a universally acceptable definition of entrepreneurship".

${ }^{5}$ However, this may also be related to the strong path dependency and complementarities in institutions, particularly financial institutions, to which we return below.
} 


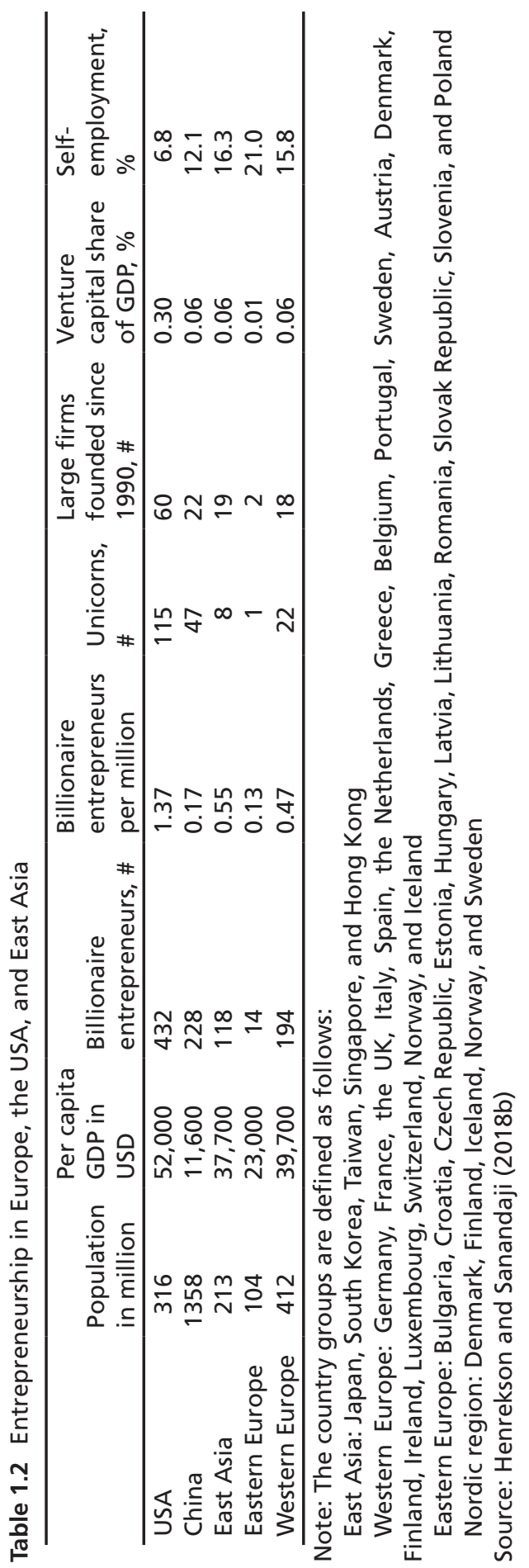


agricultural sector) among the five regions compared. In conclusion, all regions show a relatively small number of truly transformative entrepreneurs and also differ significantly in the width of the base from which such ventures grow.

Overall, the data suggest that contemporary Europe has a comparatively less fertile "ecosystem" for Schumpeterian/high-impact entrepreneurship than the USA, and in some respects even relative to China and East Asia (O'Connor et al. 2018). In Eastern Europe, much of the self-employment is marginal necessity-driven entrepreneurship, whereas in Western Europe the base of self-employment may be broad, but opportunities to grow into the global competitors of the future, in particular, seem limited. These shortcomings, we believe, explain the EU's innovation emergency and are the most significant impediments to the Union transiting to inclusive and sustainable growth; developing a broad reform strategy starts from acknowledging that Europe has a long way to go in this respect.

We should stress that a more entrepreneurial EU would benefit all strata of society and not only the few exceedingly successful Schumpeterian entrepreneurs - the latter are, more than anything else, an important measure of ex post success. In addition, of course, "the good life" cannot be achieved through material consumption alone: as highlighted by Nobel Laureate Edmund Phelps in his book Mass Flourishing (2013), individuals find meaning through flourishing as producers of offspring, goods, and services, and as actors who solve problems, face challenges, and discover, create, and act upon opportunities. Moreover, as people naturally have a strong sense of justice (Binmore 2005), these amenities in life should be open to all. Hence, while outcomes matter, the processes that lead to these outcomes matter as well. ${ }^{6}$ Part of what it means to be an entrepreneur-facing challenges and discovering, creating, and acting upon opportunities - is also part of what it means to aspire to a good life. This holistic emphasis is in line with evidence that the self-employed typically report greater job satisfaction and happiness than do employees, despite working longer hours (Blanchflower and Oswald 1998; Benz and Frey 2004). ${ }^{7}$ And the entrepreneurial process, where success and reward follow taking risks, working hard and competing on a level playing field, is perceived as both open and just. Thus, entrepreneurship not only holds the key to the future economic welfare of Europe, but is also a major ingredient in creating

\footnotetext{
${ }^{6}$ Frey et al. (2004) refer to this as "procedural utility."

${ }^{7}$ Similar findings are reported by Csíkszentmihályi (1990), who even found that most people were, in fact, happier at work than at rest.
} 
"the good life" for its citizens, which should be the ultimate goal of policymaking.

How, then, is the EU to become a more entrepreneurial society? In answering this question, our starting points are threefold. First, entrepreneurship does not occur in a vacuum; instead, it is the result of several crucial skills coming together to create value in what we term a collaborative innovation bloc. The flesh and blood actors who possess these skills are both incentivized and constrained by society's rules of the game: its institutions (cf. Welter et al. 2019).

Second, institutions are path-dependent and complementary; this means that introducing US-style institutions or any other one-size-fits-all reform strategy across Europe is destined to fail. A reform strategy is more viable when policymakers tailor it to the historical preconditions of an individual region or country or to a group of similar countries. To design such a strategy, the focus must not be on the institutions per se but on the functions these institutions perform in a well-functioning entrepreneurial ecosystem.

Third, entrepreneurship contributes to prosperity by challenging the status quo in an open market economy. Entrepreneurship thrives when open institutions create open societies where vested interests and incumbents can be challenged on a level playing field, enabling fair competition, and new ventures fail or succeed based on the value they provide to their customers and society at large.

We outline the gist of this argument in the remainder of the present chapter, in the process providing a framework for our vision of how to make the EU more entrepreneurial and innovative.

\subsection{Entrepreneurship as a Source of Growth and Inclusion}

It is a rare firm that always behaves as entrepreneurially as Schumpeter envisioned. ${ }^{8}$ But one should not dismiss less Schumpeterian entrepreneurs out of hand: Baumol (2010, p. 18), for example, distinguishes between Schumpeterian entrepreneurs and replicative entrepreneurs, who start firms that are similar to existing businesses. Replicative entrepreneurs play a crucial role during the stage of economic development that follows innovation, when a more general adoption and diffusion of new knowledge occurs (Braunerhjelm 2011; see also Baumol et al. 2007).

\footnotetext{
${ }^{8}$ In fact, Schumpeter himself argued that successful entrepreneurs will at some point turn from challengers into defenders of the status quo, and they will venture to limit competition and contestability as soon as they have conquered a strong position in their market.
} 


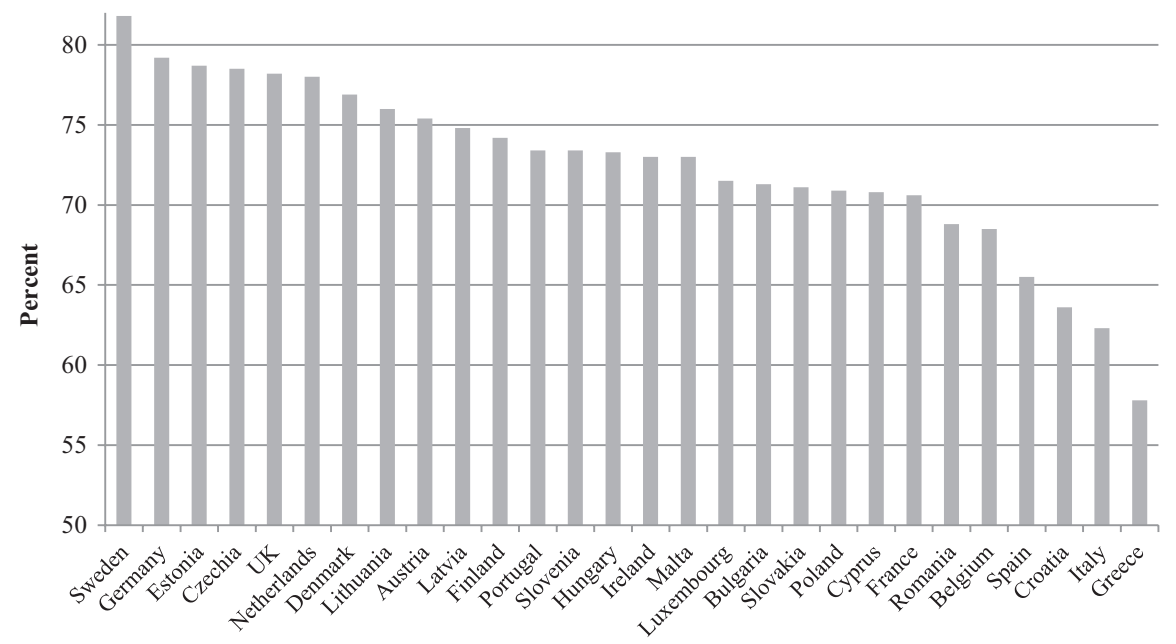

Fig. 1.1 Employment share in 2017 among people aged 20-64 in EU countries. Note: There are no data for the USA for the 20- to 64-year olds. However, in the OECD data, which reports employment rates for 15- to 64-year olds, the US employment rate was $70.7 \%$ in 2017 , compared to $76.9 \%$ in top-ranked Sweden and $53.5 \%$ in Greece, which has the lowest employment rate among 15- to 64-year olds. Source: Eurostat

Replicative entrepreneurs also help explain why few entrepreneurs capture a large share of the value they create; Nordhaus (2004) estimates that the original innovators and entrepreneurs capture, on average, a mere $3 \%$ of the value they create. This premium is so small because the existence of challengers, or the mere possibility of being challenged by new entrants, forces incumbent firms to invest continuously in innovation. Consequently, the bulk of the innovative surplus accrues to consumers in the form of lower prices and better products. Contestable, open markets are therefore a precondition for the creation of economic prosperity. Moreover, as open and contestable markets create opportunities for all and reward merit (a combination of talent, luck, and equal access to resources), the resulting wealth (re)distribution is usually perceived as equitable.

The need for more replicative entrepreneurship and more contestable markets is particularly acute in Southern and Eastern European countries marred by high levels of non-employment. Figure 1.1 shows the considerable EU cross-country variation in the need for job creation, captured by the employment rate; it ranges from $58 \%$ in Greece to approximately $82 \%$ in Sweden.

As we shall see, a great deal can be done to improve the contestability of EU markets, but this is scarcely enough to create an entrepreneurial society. Nor 
can one achieve this goal by merely ticking off the items on the usual institutional laundry list—stable property rights, the rule of law, and so on. Although ensuring that opportunities exist is crucial, it is also not enough; ideally, institutions should also ensure access to essential resources on equal terms irrespective of social background and personal wealth, thereby empowering entrepreneurs to act on these opportunities. ${ }^{?}$

European institutions did not evolve spontaneously to ensure such equitable resource access, nor have they been designed to achieve that goal. A broad range of institutions are therefore in need of reform: much broader, we argue, than the range entrepreneurship scholars and policymakers typically feel comfortable discussing. To better appreciate the scope of this challenge, we now turn to outline the ecosystem on which entrepreneurs depend to be able to innovate successfully. We label this the collaborative innovation bloc.

\subsection{The Collaborative Innovation Bloc}

Entrepreneurship scholars have long understood that entrepreneurial venturing does not occur in a vacuum. For example, the Swedish research tradition labeled the experimentally organized economy [EOE; see, e.g., Eliasson (1996) and Johansson (2009) for a synthesis] recognizes that the entrepreneurial process is inherently collaborative: to pursue their innovative projects, entrepreneurs need to cooperate with several actors whose complementary skills and resources drastically increase the probability that an innovationbased venture will be successful. The actors, skills, and resources are drawn from several sources, together forming what we call a collaborative innovation bloc. This perspective is useful for understanding how innovations come about

\footnotetext{
${ }^{9}$ This view echoes that of John Tomasi, a philosopher who promotes what he calls market democracy: a hybrid view combining insights from progressive liberals such as John Rawls and classical liberals like Friedrich von Hayek. The Rawlsian aspect of Tomasi's (2012) theory is that social justice be used as a standard to evaluate a society's institutions. In other words, inequality is only acceptable if it benefits the least well off. The classical liberal aspect is that economic freedom be considered one of citizens' most important rights, since it is necessary for self-authorship, a Rawlsian term that Tomasi describes as (2012, p. 40) "the capacity to develop and act upon a life plan (whether that plan be individual, collective, or otherwise shared). People are life agents and their agency matters. As responsible self-authors, they have the capacity to realistically assess the options before them and, in light of that assessment, to set standards for a life of a sort that each deems worth living." This view is shared by, e.g., Deirdre McCloskey (2010, p. 74): "The economic history of innovation ... fulfils the so-called difference principle of the philosopher John Rawls ... that a change is ethically justified when it helps the very poorest. Markets and innovation did."
} 
in a modern economy and how the institutional framework of that economy ought to change to achieve more innovation and prosperity. ${ }^{10}$

An economy's institutional framework is commonly conceptualized as "the humanly devised rules of the game" that determine people's incentives to acquire, utilize, and share their resources (North 1991, p. 97). An implication of the EOE perspective's actor and resource complementarity is that institutions have a more substantial effect on innovation and growth than an analysis focusing on any one actor would suggest (cf. Phelps 2007, p. 553). The mobilization of actors and resources in the collaborative innovation bloc is a daunting task for the entrepreneur in the best of circumstances. ${ }^{11}$ Generally, institutions must enable the emergence of a minimum critical mass and variety of skills and resources before innovation-based venturing can have a high probability of success. The number, variety, and character of actors determine the shape and intensity of the competition between collaborative teams for the scarce resources at hand, as well as their incentives to learn, experiment, and collaborate.

When employed successfully, the entrepreneurial meta-skill of gathering and jointly combining these skills and resources makes it possible to turn an innovation into a good or a service that is produced and sold on an industrial scale in competition with innovations created by other collaborative teams and the older technology offered by incumbents. When economic institutions interact with such meta-skills, they shape the exchange and collaboration that ultimately determine access to such skills and resources (Spigel and Harrison 2018). Competition between various collaborative teams will bring about an evolution of collaborative innovation blocs in the entrepreneurial ecosystem. Since the resulting innovations drive out, or at least challenge, incumbents, this process generates aggregate economic growth in the experimentally organized market economy (Elert and Henrekson 2019) and drives the process of creative destruction as conceptualized by Joseph Schumpeter (Aghion and Howitt 1992; Caballero and Jaffe 1993).

\footnotetext{
${ }^{10}$ The EOE perspective shares many features with the more recent literature on entrepreneurial ecosystems (Stam 2015; Autio 2016; O'Connor et al. 2018) and the national system of entrepreneurship approach (Acs et al. 2014), but we can trace its roots back to the works of Swedish economists Johan Åkerman and Erik Dahmén; see Erixon (2011) and Dahmén (1970). While these other perspectives offer valuable insights, they seldom make a clear distinction between actors and institutions, and "the institutional variables that are used, such as technology absorption, gender equality, R\&D spending, and depth of capital markets, are not institutional variables; they are outcomes resulting from the evolution of the economic system in a given institutional setup" (Braunerhjelm and Henrekson 2016, p. 101).

${ }^{11}$ For one thing, knowledge is often tacit (i.e., difficult to transfer to another person by means of written documentation or verbalizing it) and non-communicable (Hayek 1945). Moreover, labor contracts are necessarily incomplete and access to finance for early-stage ventures is limited.
} 


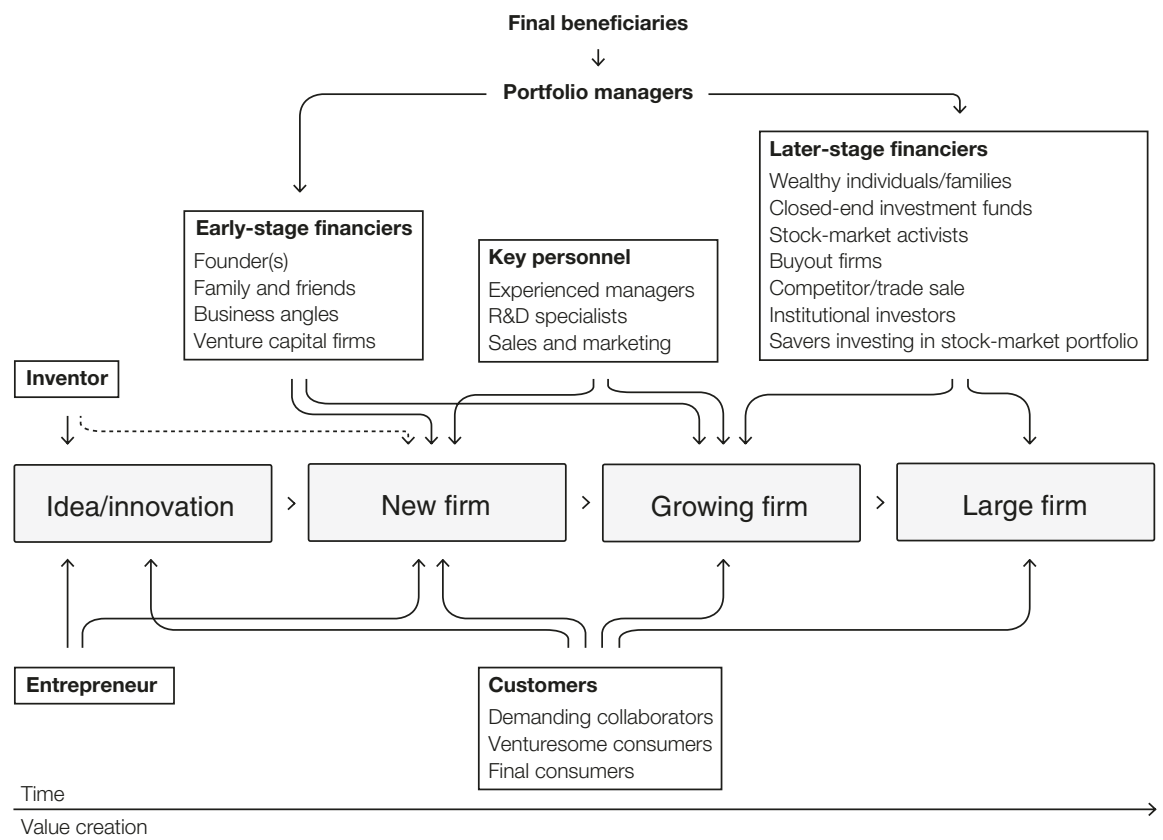

Fig. 1.2 The collaborative innovation bloc-an overview. Note: Financing by founders (using their assets or retained earnings) and by passive individual and institutional investors (in either phase) is not included in the diagram. Source: Elert and Henrekson (2019)

Figure 1.2 provides a schematic overview of the structure and resources required for a new idea to transform into a growing firm that eventually reaches maturity [as described by, e.g., Fenn et al. (1995) and Gompers and Lerner (2001)]. The agents and resources in the collaborative innovation bloc fall into six categories: entrepreneurs, inventors, key personnel, early-stage financiers, later-stage financiers, and customers. Below, we draw on Elert and Henrekson (2019) to briefly describe the six categories.

1. The entrepreneur: Treating the entrepreneur as a collaborator is not a new approach; in fact, Schumpeter (1989 [1949], p. 261) argued that the entrepreneurial function "may be and is often filled cooperatively," and several perspectives on entrepreneurship acknowledge this fact (e.g., McCloskey and Klamer 1995; Cosgel and Klamer 1990; Lazear 2004). In the EOE perspective, entrepreneurs create new collaborative teams, both searching for and attracting the skills and resources they perceive to be necessary to realize their projects. In this role, they benefit from existing collaborative blocs and also create new blocs and help existing blocs evolve. Consequently, 
the institutional infrastructure supporting entrepreneurship often emerges as a product of a critical mass of entrepreneurship in an industry or a set of related industries (Stam and Lambooy 2012).

2. Inventors: Entrepreneurs generally have an excellent overall understanding of how to exploit an opportunity but may lack specific knowledge regarding relevant technologies. Conversely, while inventors can be involved in founding teams, there is no reason to assume that they have a comparative advantage in bringing new ideas to the market as a good or service. In fact, Schumpeter (1934 [1911]) distinguished between inventors and entrepreneurs, but the nuance was lost when modern growth models (e.g., Romer 1990; Aghion and Howitt 1992) collapsed invention, innovation, and commercialization into one decision (Acs and Sanders 2012, 2013).

3. Key personnel: While much has been said about the market's Hayekian knowledge problem - the fact that knowledge of the particular circumstances of time and place is dispersed (Hayek 1945) — such a problem is consistently present within firms and increasing with the size of the organization (Foss 1997). In times of rapid firm growth and development, key personnel such as professional managers, skilled specialists, production staff, and front-line personnel may contribute skills that are essential to an entrepreneurial venture (Sautet 2000). ${ }^{12}$ They will only be able to do so if they are allowed to act upon the knowledge only they possess to promote intra-firm learning and local discoveries (Foss 1997; Pongracic 2009). Detailed evidence on the sequence in which ventures typically draw on such resources suggests that founder teams and employees grow more rapidly for radical product innovations than for incremental service innovations (Held et al. 2018b).

Determining the relative importance of the different skills that key personnel contribute is challenging. While much of the mainstream entrepreneurship and economics literature sees $\mathrm{R} \& \mathrm{D}$ teams and technical specialists as key to innovation (Audretsch et al. 2006; Chandler 1990), turning high-level ideas into commercially viable products seldom involves much in the way of high-level R\&D. As Bhidé (2008, pp. 150-151) puts it, "the commercial success of innovations turns not just on the attributes of the product or know-how, but on the effectiveness and efficiency of the innovator's sales and marketing process." As an entrepreneurial venture grows, so does its need for professional managers with an expertise in taking the

\footnotetext{
${ }^{12}$ Labor market institutions largely determine whether they do so as employees or as independent consultants. Held et al. (2018b) show that while employees and founder team members are complements, external expertise can substitute for in-house employees.
} 
business to a mature stage and mitigating the internal knowledge problem (Sautet 2000) so that misuse and conflict do not impede the discovery, exploitation, and sharing of local knowledge (Ghoshal et al. 1995).

4. Early-stage financiers: The founder's equity (possibly complemented by (soft) loans from family and friends) often finances a firm's early phase, but external equity financing is usually necessary if a new entrepreneurial firm is to grow into a significant industry player. Debt finance plays a minor role at this stage of the firm life cycle because of the high risk and typically negative cash flow. Nonetheless, start-ups sometimes do obtain business loans early on, and founders frequently pledge personal assets and wealth as collateral to obtain loans to finance their ventures (Held et al. 2018a). Research shows that such business loans positively affect survival and growth (Cumming and Groh 2018; Cole and Sokolyk 2018). Similarly, Landström and Mason (2016) show that early-stage external equity finance matters for nonfinancial reasons. Business angels, and also banks, play an instrumental role in providing tight screening and close monitoring of the firm's progress, markedly reducing moral hazard problems. Hence, the early involvement of an external, disciplining entity in the firm is as important as the financial resources per se. VC investors, who usually come in later in the life cycle, would have far fewer potentially successful candidates to choose from, were it not for these earlier contributions.

Individuals with extensive experience in the industry in which they invest often perform the business angel and VC function (Busenitz et al. 2014). When circumstances are appropriate, they can combine several high-risk opportunities to achieve a more acceptable overall risk level through portfolio diversification; they identify entrepreneurs and their projects, determine whether and how much to invest, and decide how the investment should be valued. Importantly, they also contribute critical skills to the entrepreneurial venture, such as management expertise, market knowledge, and access to their business networks. If need be, they can also enforce change and appoint new management better equipped to lead the company. Thus, a varied and competent VC industry can provide a crucial component of the early-stage selection machinery of the collaborative innovation bloc. Provided such a sector exists and is sufficiently developed, diversification across VC funds makes it possible even for actors with low risk tolerance, such as institutional investors and banks, to invest in start-ups and innovative ventures. That said, the VC business model is labor intensive and has proven hard to scale up (Polzin et al. 2018a). This may help explain the recent emergence of platform-based alternatives to "traditional" business angel and VC markets, such as equity (Estrin et al. 
2018) and debt crowdfunding (Hornuf and Schwienbacher 2018; Signori and Vismara 2018). While still marginal in size, these new sources of finance currently grow at double or even triple digit rates, and they are particularly open to the relatively modest amounts commonly demanded in entrepreneurial venturing (Polzin et al. 2017).

5. Later-stage financiers: Well-functioning exit markets are crucial to (a) incentivize VC firms by enabling them to unload their investments when their operations have run their course (Eliasson 2000) and (b) provide entrepreneurs with the large equity infusions typically required to turn a nascent venture into a sizable firm. In the case of sustained inferior performance, later-stage financiers also assess whether there are potential profits from assuming control and replacing the entrepreneur and the firm's top management.

The most common exit strategy is through a trade sale, in which the entrepreneur/founder hands over full control to the buyer (usually another firm in the same industry). A trade sale is likely an indication that the firm currently lacks some crucial skill or resource (e.g., distribution networks and marketing expertise), making an independent scaling up of its operations unfeasible or too risky (Lerner and Tåg 2013). Another important exit market actor is the buyout firm, which operates much like a VC firm, albeit dealing with much larger sums. Evidence suggests that buyouts lead to a reallocation of firm resources to more productive uses (Tåg 2012; Olsson and Tåg 2017), partly by bringing in better knowledge of management practices (Bloom et al. 2009) and access to resources, infrastructure, and networks that are particularly relevant when scaling up (Duruflé et al. 2017). Wealthy industrial families and owner activists are also important actors in the secondary market; whether any of them will be able to act in a forceful manner depends, in no small measure, on the extent to which they can expect capital infusions from passive investors (such as pension funds and open-ended stock market funds) if the firm develops well. Of course, the functioning of exit markets depends on the prevailing institutions that shape incentives and payoffs for venture owners and acquirers alike.

6. Competent customers: Consumers are the ultimate arbiters of an innovation's success, yet they hardly appear in the cast in most accounts of innovation. The omission is regrettable; Bhidé (2008) defines "venturesome consumption" as the willingness and ability of intermediate producers and individual consumers to take a chance on and effectively use new knowhow and products and argues that it may be as crucial to a country as its capacity to undertake high-level research. Even in an entrepreneurial venture's early stages, demanding collaborators can function as particularly 
important sources of information on consumer needs and preferences. Sometimes, they even act as strategic partners, taking an active part in the development and commercialization of products (Bhidé 2008; von Hippel et al. 2011). In the extreme, when qualified venture capitalists are absent, large enterprises rich in capital often step in to play this role. However, this substitution is unlikely to yield radical innovations because it restricts such financing to technologies close and complementary to those of the partnering industry (Eliasson 2000).

The outline above should give an idea of the interconnectedness of the agents and resources in a collaborative innovation bloc. Certainly, the details of the commercialization process vary, and actors typically work alongside each other or overlap during different phases. Frequently, however, the process begins when an entrepreneur identifies a potential opportunity through her interactions with demanding customers, which she then strives to develop together with an inventor into a successfully commercialized innovation. Generally, the early commercialization phase mainly involves entrepreneurs and, to a lesser extent, key personnel (Held et al. 2018b). In this experimental stage, uncertainty is high and equity financing is critical, but debt financing can also play an important role. A study covering the USA, the UK, Germany, and Italy found that up to $10 \%$ of start-ups acquired loans in their first or second round of funding (Held et al. 2018b), and debt-financed ventures also tend to do well in terms of innovation and growth, as long as the debt is not the personal debt of the founder (Cole and Sokolyk 2018).

Early-stage financiers usually propel the project into a scale-up phase, during which the conjectured entrepreneurial profits can be realized (assuming the project reaches this point). At this stage, the entrepreneur requires more key personnel, often with highly specialized skills. Later-stage financiers assume responsibility for financing, which (depending on the sector) may be substantial. In parallel, competitors begin to imitate the innovation if they perceive it to be promising, and the market grows through the operational scaling-up of activities resulting from differential growth and selection (Metcalfe 1998). Eventually, the process stabilizes (Witt 1996), with the market taking the form of a monopoly, an oligopoly, or a competitive situation involving multiple actors. By this point, organizational behavior, strategy, and business models will have become relatively uniform and standardized. While entrepreneurial profits are often exhausted at this point (Dopfer and Potts 2009), the scope for innovation is by no means exhausted: firms can, for example, introduce more efficient production and distribution methods or change the attributes of a good or a service to enhance its value. 
Part of what it means to be an entrepreneur is having the ability to gather actors with different skills and resources in a collaborative innovation bloc and productively combine them into a collaborative team. From the above, we can broadly distinguish knowledge, finance, and labor as the key resources an entrepreneur needs to acquire, with the emphasis shifting between them in different stages of the venture process. This suggests that entrepreneurs indeed must be "jacks-of-all-trades" (Lazear 2004) and possess a broad and balanced skill mix. Even then, the task may be arcane for any individual if the bloc in question is not of sufficient breadth and depth. Moreover, the institutional context in which teams compete determines the supply of these scarce resources and the conditions under which teams compete for them. It is in this context that economic policy and the institutional framework underpinning the innovation bloc come into play.

\subsection{No One-Size-Fits-All Strategy}

Scholars began to examine the link between institutions and entrepreneurship in earnest following William Baumol's (1990) landmark paper establishing that the way a society's institutions structure economic payoffs influences the nature of entrepreneurial efforts and activities (Baumol 1990; see also North 1990; Murphy et al. 1991; Sobel 2008; Acs et al. 2008; Stenholm et al. 2013; Calcagno and Sobel 2014; Urbano and Alvarez 2014). The current literature suggests that entrepreneurship takes different forms between countries or regions because of institutional differences (see, e.g., Case and Harris 2012; WEF 2013; Stam 2014), and the (formal) institutions thought to be particularly important in this respect include the protection of private property, the rule of law, intellectual property rights, tax codes, social insurance systems, employment protection legislation, and competition policy (Hall and Jones 1999; Henrekson and Johansson 2009; Bjørnskov and Foss 2013). ${ }^{13}$ Reform directed towards more entrepreneurship-friendly institutions in these areas should, the reasoning goes, improve the environment for entrepreneurial venturing in Europe.

This reasoning is correct, subject to some caveats. For one thing, as Samuel Bowles (2016) has argued in his thoughtful book The Moral Economy, incen-

\footnotetext{
${ }^{13}$ Informal institutions influencing entrepreneurship include social capital, trust, inclusiveness, individualism, power distance, and uncertainty avoidance (Hechavarria and Reynolds 2009; Taylor and Wilson 2012). Policymakers should take them into account when they fit reform proposals to local contexts, but as these institutions are much less amenable to reform and policy interventions, they are beyond the scope of this book. The interested reader is referred to a longer discussion in Elert et al. (2017, pp. 71-74).
} 
tives are a double-edged sword: incentivizing policies can erode individuals' intrinsic social motivations unless policymakers combine them with a convincing moral message. In our context, this means that institutional reforms directed towards an entrepreneurial society will likely only be effective if accompanied by recognition of the importance of entrepreneurship. According to McCloskey (2016), such a cultural shift goes a long way towards explaining the innovative miracle that created the modern world during the industrial revolution. Bowles (2016) also notes that monetary incentives should never be divorced from the policy process that introduced or allowed for them; reforms risk backfiring if they are imposed without public consultation and buy-in. Here, of course, the national and local contexts are crucial.

While the EU has seen top-down and bottom-up convergence over the years, even member states with similar levels of per capita income continue to differ substantially in their institutional organization. The diversity is not surprising given the documented importance of historical values and norms, lock-in effects, and path dependency in institutional evolution (Arthur 1989; Reher 1998; Acemoglu et al. 2001; Nunn 2009; Alesina et al. 2015). Indeed, these cross-country differences are a starting point in the various incarnations of the varieties of capitalism ( $\mathrm{VoC}$ ) literature, which is closely associated with the seminal work of Hall and Soskice (2001). Research in this tradition sees the existence of institutional complementarities as the main driver of the persistence of institutional differences across $\mathrm{VoC}$, with institutions being complementary "if the presence (or efficiency) of one [institution] increases the returns from (or efficiency of) the other" (Hall and Soskice 2001, p. 17). ${ }^{14}$ Specifically, it makes little sense for European member states to try and emulate US-style alumni donations to universities or Chinese-style infrastructure investments when the supporting cultural and deeply embedded, historically evolved complementary institutions are absent. It is better to look at the best of your closest peers and adopt, e.g., German-style apprenticeships or Finnish educational policies.

The VoC literature illustrates how a distinct set of institutions governs the exchange between companies and their national labor markets, financial markets, and research and development infrastructure. The particulars of this syn-

\footnotetext{
${ }^{14}$ One salient example is the sizeable cross-country variation in corporate governance models of large listed firms: It ranges from the archetypical Anglo-American model based on management control and dispersed ownership, to various models of concentrated family control by means of dual-class shares, pyramiding, and cross-ownership, common in Europe and Asia (Bebchuk and Roe 2004). The complementarity of elements in these specific corporate governance models is crucial. Reforms limited to a particular element risk giving rise to inconsistencies that make the overall model less efficient (Schmidt and Spindler 2002).
} 
ergy translate into different innovation, technology, and production outcomes across economies - varieties of capitalism that are thought to be particularly stable because of the complementarities between their underpinning institutions. The perspective helps explain the nonrandom interconnectedness of various institutions, the persistence of institutional forms that are (seemingly) not conducive to entrepreneurship and growth, and thus the prospects for amending these institutions.

To date, however, the $\mathrm{VoC}$ literature has largely neglected entrepreneurial venturing, evolving instead through studies of incumbent firms and the institutions channeling their behavior. Dilli et al. (2018) filled this research gap by illustrating how distinct institutional constellations relate to specific types of entrepreneurship in a study focusing on the USA and 20 European economies: countries fall into four distinct families or clusters with a similar set of institutions governing finance, labor markets, education and training, and inter-firm relationships. According to Dilli et al. (2018), these constellations facilitate the development of different types of entrepreneurship, ranging from risk-loving, growth-aspiring ventures based on radical innovations to risk-avoiding, growth-averse ventures based on imitation.

These findings are both discouraging and revealing. If distinct institutional constellations govern the emergence of distinct forms of entrepreneurship, then merely pushing a regulatory button in isolation is unlikely to yield the desired results. Such an action might even make matters worse if it removes or weakens an institution whose presence is essential for the working of other institutions in the complex web that comprises the entrepreneurial ecosystem. For example, implementing some isolated fiscal reform to strengthen incentives for VC providers would hardly be effective in facilitating more Schumpeterian entrepreneurship in Continental, Southern, and Eastern Europe. To achieve this goal, policymakers more likely need to deregulate both labor and financial markets in a sensible manner so that VC-funded ventures can also hire and fire employees more freely, implement strong incentive contracts for founders, and a viable exit market is allowed to emerge. Only under those conditions the classical VC model can actually function. Reform failure is likely if policymakers do not take these important institutional complementarities into account.

However, the steps necessary in an appropriate and effective reform strategy are similar across $\mathrm{VoC}$ at a sufficiently high level of abstraction. In all regions and countries, one must begin by assessing the most salient features of the institutional framework in place and tracing its historical roots. This makes it possible to assess strengths and weaknesses and identify bottlenecks in the entrepreneurial ecosystem using the structured analysis of primary and secondary data. These insights should then be applied to a menu of evidence- 
based policy interventions, allowing appropriate interventions to be selected and tailored to fit the specific country or region by heeding the relevant local, regional, and national institutional complexities. In this book, we present such a menu of evidence-based policy interventions for six institutional areas that we identify as particularly critical to the creation of flourishing collaborative innovation blocs and, ultimately, an entrepreneurial society. ${ }^{15}$ Looking across the proposals developed in this book, we identified a set of common core principles that we believe can inform and guide reform proposals in any specific context.

\subsection{Principles}

The common principles underlying all proposals in this book are: neutrality, transparency, moderation, contestability, legality, and justifiability. These words can take on different meanings depending on the context in which they appear, meaning that we must take care when explaining how we employ them when formulating our reform agenda. Below, we briefly discuss each of these six principles.

Frequently, neutrality is described as the state of not supporting or helping either side in a conflict or disagreement. It may seem odd for a book arguing in favor of entrepreneurship to adopt this principle. In actuality, however, we rarely argue that policymakers should bestow favors upon entrepreneurs because they do not need to be pampered. Instead, we wish to level the playing field between entrepreneurs and those they challenge- a playing field that at present is all too often tilted against entrepreneurs. Adhering to the neutrality principle, which implies that a level playing field is restored and maintained, will often already go a long way towards supporting entrepreneurs in their efforts.

Transparency, as commonly used, means operating in such a way that it is easy for others to see what actions are performed and what consequences they will entail. As such, transparency implies openness, communication, and accountability. This principle guides many proposals because it is essential for

\footnotetext{
${ }^{15}$ The evidence base is not equally extensive for all proposed interventions; the policymaking world is not a laboratory, meaning that data on the impact of the proposed interventions are often absent. If we restricted our menu to evidence-based policies only, we could only include policies that policymakers have already implemented somewhere. More radical ideas and suggestions would not qualify. In such cases, we present the arguments and propose that policymakers implement the reforms with caution. The implementation of such policy suggestions will aid in building an evidence base, provided that they are carefully designed and evaluated.
} 
(potential) challengers to know the criteria upon which their venture will be evaluated. Ensuring more transparency about the criteria that determine how labor, knowledge, and financial resources are made available to new ventures would, we believe, reduce this source of uncertainty in entrepreneurial venturing.

Moderation is commonly defined as the avoidance of excess or extremes or the process of eliminating or lessening extremes. This principle underlies many of our proposals in the realms of taxation and subsidization, as excessive interventions are particularly damaging in these areas. Furthermore, uncertainty is all around us, including when making policy and implementing institutional reforms. The future is unknowable; therefore, policymakers should be modest in extracting and allocating resources lest such measures become costly to reverse.

Contestability is a key for entrepreneurial venturing and also for policymaking. When followed, this principle entails that all vested positions, opinions, and truths should be open to challenge and debate. Such openness lends legitimacy to the status quo and ensures that institutions support those ventures that represent the best of our knowledge to date. If institutions, policies, and markets cease to be contestable, they risk becoming outdated and obsolete in an ever-changing environment. Contestability is thus the cure for sclerosis and rigidity.

Legality refers to the idea that de jure and de facto institutions need to coincide, such that legality ensures the rule of law is both upheld and aligned with the institutional framework. This principle is a fundamental precondition in all modern economies and underpins any liberal democratic political orderto the point that it is occasionally taken for granted in much of the EU. Nevertheless, it is important to realize that formally enacting the appropriate laws does not automatically ensure the legality of institutions that support an entrepreneurial society.

Justifiability refers to the appropriate balancing of public and private interests that is needed to justify policy interventions beyond a simple laissez-faire attitude. Moreover, not only active policies and institutions need to be justified but also passive institutions, such as (intellectual) property rights, if they are to be effectively implemented and respected. If institutions are perceived to benefit entrepreneurs at the expense of their consumers, employees, inventors, financiers, or society at large, these institutions cannot be justified and should be reformed to ensure a long-run stable license to operate for entrepreneurs that seek to challenge the status quo.

In our more concrete proposals for institutional reform discussed below, most proposals can be related to one or more of these underlying principles. We also believe that with these principles in hand, many more potentially 
effective reforms can be conceptualized for specific contexts. We present them here, individually and together, as essential guidelines for drafting an effective reform strategy that supports innovative, inclusive, and sustainable growth at any level of aggregation and policymaking.

\subsection{Book Outline}

The principles outlined above safeguard the coherence of our overall reform strategy by making it easier to structure the discussion and weigh proposals against one another. For the sake of concreteness, we also identify the governance level that has the power and/or competence to implement the proposed reforms. As our book seeks to be useful for policymakers, we have chosen to structure our proposals along six broad policy areas. The six reform areas we discuss in separate chapters in the remainder of this book are as follows:

1. The rule of law and protection of property rights: These institutions are fundamental to any market economy and crucial to any attempt to build an entrepreneurial society. To understand how they can be strengthened in an entrepreneurship-friendly manner across the EU, we first emphasize the principle of legality, i.e., considering de facto rather than de jure institutions. Moreover, the protection of property rights cannot be absolute; in particular, the realm of intellectual property requires a careful balancing of public and private interests to ensure justifiability. Given the European Commission's competencies in international negotiations on these issues, a clear and actionable reform agenda presents itself.

2. Taxation: In this chapter, we systematically cover all areas of taxation that we deem relevant to an entrepreneurial society. Such an exercise is important because taxes shape and bias the incentives for corporations, individuals, and organizations. The principles of moderation, neutrality, and transparency guide us when we propose reforms in this area. Biases in favor of entrepreneurship can sometimes be justified in the case of strong positive external effects, but more often, we argue for leveling the playing field and moderate taxation to restore or maintain market incentives. Since the EU typically has limited capabilities in terms of taxation, we primarily address such reforms at the level of the member states, carefully discussing the direction in which they could reform their tax systems in support of a more entrepreneurial society.

3. Savings, finance, and capital: Here, we cover the institutions that govern the intermediation of savings across Europe while adhering to the princi- 
ples of neutrality, transparency, and justifiability. History and evolution have created a largely bank-based and highly regulated system of financial markets in which wealth and savings are predominantly "locked-up" in professionally managed funds and assets. In such a system, investees without collateral, strong balance sheets and long track records are fighting an uphill battle to gain access to credit and financial resources, whereas important public interests (e.g., in a secure payment system and stable pension funds) require careful balancing against the needs of the entrepreneurial society. The principles help us offer proposals aimed at leveling the playing field and mobilizing more of Europe's ample financial resources for entrepreneurial ventures. Given the shared competencies in this area, most proposals in this chapter are addressed towards both the EU level and the member states.

4. Labor markets and social security: To a large extent, these institutions determine the allocation of human resources, notably skilled labor, to entrepreneurial ventures. Again, these culturally deeply embedded systems typically favor large, stable incumbent firms, meaning that experimental, innovative ventures struggle to obtain human resources. Our proposed reforms do not follow the naïve neoliberal logic of all-out liberalization but rather aim to improve the situation for entrepreneurs and employees in Europe by making rights more portable and social security more universal and unconditional. The principles of moderation, neutrality, contestability, and justifiability all play important roles in this area. As in the case of taxes, our proposals in this chapter are addressed to the member states primarily, as they retain most legal competencies in this area.

5. Contestable markets for entry and exit. This is an area of strong and extensive EU competencies by virtue of the single market, but Europe can do more to promote contestable markets for entry and exit. Here, we draw on the principles of contestability, transparency, and justifiability to better understand how reforms ensuring a vibrant entrepreneurial society can come about. Lower entry barriers and functionally specified quality standards are key to this reform area, especially for services, where in the (semi-)public domain (e.g., health care and education), there is room for productive venturing under appropriate constraints. To facilitate entry in many sectors, exit must also be well arranged, leading us to proposals in the area of bankruptcy law and the smooth liquidation of outdated and failed ventures.

6. Mobilizing human capital for entrepreneurship: Since the Treaty of Lisbon, innovation policy is part of the European Commission's competencies, but we have yet to see institutional reform actions to promote the building of a European knowledge space where useful knowledge flows freely to the 
benefit of both incumbents and challengers. When formulating proposals in this direction, we draw on the principles of justifiability and contestability to ensure that the positive externalities of knowledge creation and diffusion through commercialization are balanced with private interests of privacy and competitive advantage.

After discussing no less than 50 proposals in these six policy areas, we conclude this volume with a chapter that sketches the agenda for future research and, more importantly, policy reform. We would also like to alert interested readers to the (forthcoming) companion volume The Entrepreneurial Society Part II: Implementing the Reform Strategy for Italy, Germany and the UK (Marx et al. 2019), which complements this volume by illustrating how the menu of reforms presented here can be prioritized and adjusted to specific Varieties of Capitalism in member states across Europe.

Open Access This chapter is licensed under the terms of the Creative Commons Attribution 4.0 International License (http://creativecommons.org/licenses/by/4.0/), which permits use, sharing, adaptation, distribution and reproduction in any medium or format, as long as you give appropriate credit to the original author(s) and the source, provide a link to the Creative Commons licence and indicate if changes were made.

The images or other third party material in this chapter are included in the chapter's Creative Commons licence, unless indicated otherwise in a credit line to the material. If material is not included in the chapter's Creative Commons licence and your intended use is not permitted by statutory regulation or exceeds the permitted use, you will need to obtain permission directly from the copyright holder.

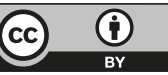

